CLINICAL STUDY

\title{
Association of an A/C single nucleotide polymorphism in programmed cell death-ligand 1 gene with Graves' disease in Japanese patients
}

\author{
Mina Hayashi, Tsuyoshi Kouki, Nobuyuki Takasu, Sumito Sunagawa and Ichiro Komiya \\ Department of Endocrinology and Metabolism, Internal Medicine, University of the Ryukyus, Uehara 207, Nishihara, Okinawa 903-0215, Japan \\ (Correspondence should be addressed to T Kouki; Email: tkouki@ryudai2nai.com)
}

\begin{abstract}
Objective: Programmed cell death-1 (PD-1) and its ligands (PD-L1 and PD-L2) inhibit T-cell proliferation and activation. This inhibition down-regulates the immune responses. The association of a PD-L1 polymorphism with Graves' disease (GD) was studied.

Design: The association of an A/C polymorphism at position 8923 in PD-L1 intron 4 with GD was studied. Patients: The study included 327 GD patients and 192 controls, of which 252 GD patients were followed over 5-10 years.

Measurements: PD-L1 intron 4 position 8923 A/C polymorphism was typed using the PCR-restriction fragment length polymorphism method.

Results: The A/C genotype frequencies were significantly different between GD patients and controls. The $\mathrm{A} / \mathrm{C}$ and $\mathrm{C} / \mathrm{C}$ frequencies were higher in GD patients than in controls. The $\mathrm{A} / \mathrm{A}$ frequencies were lower in GD patients than in controls. C-allele frequency was higher in GD patients than in controls. A total of 252 GD patients were followed over 5-10 years; 200 had discontinued antithyroid drugs (ATD) while 52 continued to take ATD. Of these 200, 176 continued to be in remission and 24 had relapsed into hyperthyroidism. Significant differences in the duration of positive TBII, positive thyroid-stimulating antibodies, and ATD treatment were noted between the patients in remission and those that had relapsed. Significant differences in the A- and C-allele frequencies were noted between the two. The C-allele frequency was higher in GD patients who did not achieve remission than in those who achieved remission. Conclusion: An A/C polymorphism at position 8923 in PD-L1 is associated with GD. The PD-L1 polymorphism plays a role in GD development. GD patients with the $\mathrm{C}$ allele at position 8923 in PD-L1 gene had difficulty in achieving remission.
\end{abstract}

European Journal of Endocrinology 158 817-822

\section{Introduction}

Graves' disease (GD) is a thyroid-specific autoimmune disorder associated with a T-lymphocyte abnormality (1). GD develops as a result of a complex interaction between genetic susceptibility genes and environmental factors $(1,2)$.

Programmed cell death 1 (PD-1) receptor and its ligands (PD-L1 and PD-L2) inhibit T-cell proliferation and activation (3). This inhibition down-regulates the immune responses (3). The PD-1 pathway is involved in the development of autoimmune diseases (4). PD-L1 and PD-L2 are ligands for PD-1 (5). PD-L1 is expressed on antigen-presenting cells such as dendritic cells and monocytes, on a subpopulation of $\mathrm{T}$ and $\mathrm{B}$ cells, and constitutively on parenchymal cells (6). PD-1 inhibits T-cell proliferation $(7,8)$. PD- 1 and its ligands play a crucial role in the down-regulation of immune responses.

The alteration of the PD-1 and its ligand genes may contribute to the development of autoimmune diseases.
PD-1 gene polymorphisms have been reported to be associated with systemic lupus erythematosus (SLE) (9, 10), type 1 diabetes (T1D) $(11,12)$, rheumatoid arthritis (13), multiple sclerosis (MS) (14), and ankylosing spondylitis (AS) (15). A PD-L2 gene polymorphism is associated with susceptibility to SLE (16). Newby et al. (17) reported tag single nucleotide polymorphism (SNP) screening of the PD-1 gene for an association with GD.

A reduced expression or function of PD-L1 due to gene polymorphisms may induce an augmentation of the T- or $\mathrm{B}$-cell responses. This augmentation of the T- or B-cell responses may lead to the development of autoimmune diseases. There are seven SNPs in the PD-L1 gene, which have so far been observed in the Japanese population (JSNPs database (http://snp.ims.u-tokyo.ac.jp/index. html)). Several gene polymorphisms have been reported in PD-L1 gene (12). However, no association between PD-L1 gene polymorphisms and autoimmune diseases has yet been reported. This study characterized the association between these PD-L1 gene polymorphisms 
and GD. This is the first report to demonstrate an association between a PD-L1 gene polymorphism and GD. An A/C polymorphism at position 8923 in PD-L1 gene affects the GD development.

\section{Methods}

\section{Subjects}

Whole blood specimens with EDTA were obtained from the subjects. The subjects were recruited between 1 January 1993 and 31 December 2001. They were all Japanese. A total of 327 patients with GDs were studied (262 women and 65 men, aged 15-75 years). An A/C polymorphism at position 8923 in PD-L1 gene was analyzed in these 327 Graves' patients. A total of 252 Graves' patients were followed over $5-10$ years. The other 75 Graves' patients were not followed. In addition, the 192 normal control subjects were also observed (154 women and 38 men, aged 19-75 years). These 192 normal control subjects did not have a goiter. They also denied any personal or family histories of autoimmune thyroid diseases. They were negative for thyrotrophin (TSH) receptor antibodies (TRAb), thyroglobulin antibodies (TGAb), and thyroid peroxidase antibodies (TPOAb). GD was diagnosed on the basis of histories and signs of hyperthyroidism with diffuse goiter and the laboratory findings, including elevated serum thyroxine $\left(\mathrm{T}_{4}\right)$ and tri-iodothyronine $\left(\mathrm{T}_{3}\right)$ concentrations, undetectable serum TSH levels, and positive $\operatorname{TRAb}(18,19)$. TRAb was measured as TSH-binding inhibitory immunoglobulins (TBII) (20) and thyroid-stimulating antibodies (TSAb) (18). TBII was measured using a commercially available kit (RSR Ltd, Cardiff, UK). A receiver operating characteristic curve analysis (21) was conducted to evaluate the TBII and TSAb values for the GD diagnosis (20). The cutoff value for TBII was 10\% (sensitivity $95.67 \%$ with 95\% confidence limits (93.27-98.07\%) and specificity $98.69 \%$ with $95 \%$ confidence limits (97.84-99.54\%))
(20). TSAb was measured in the same manner as reported previously (18), using a commercially available kit (Yamasa, Chiba, Japan). The cutoff value for TSAb was $180 \%$ (sensitivity $96.14 \%$ with $95 \%$ confidence limits (94.64-97.64\%) and specificity 98.62\% with 95\% confidence limits (97.87-99.37\%)) (18).

Table 1 shows the clinical findings of the 252 Graves' patients who had been followed for 5-10 years. After the diagnosis of GD was made, the patients were treated with methimazole (or propylthiouracil; antithyroid drugs (ATD)) at initial doses of 20-30 (or 200-300) mg/day. These doses were gradually reduced. They received the minimum doses of ATD necessary to maintain the normal levels of serum $\mathrm{T}_{4}, \mathrm{~T}_{3}$, and TSH. The patients were seen every 2-4 weeks until their serum $\mathrm{T}_{4}$ and $\mathrm{T}_{3}$ concentrations had become normal. They were then followed every 4 weeks. TBII and TSAb were measured every 1-3 months. Of the 252 patients, 200 of them (group 1), who had had negative TBII and negative TSAb and normal serum levels of $\mathrm{T}_{3}, \mathrm{~T}_{4}$, and TSH over the previous 1 year, had discontinued ATD, while 52 patients (group 2), who continued to have positive TBII and/or positive TSAb, continued to take ATD. The 200 patients (group 1), who had had negative TBII and negative TSAb and normal serum levels of $\mathrm{T}_{3}, \mathrm{~T}_{4}$, and TSH over the previous 1 year, had all discontinued ATD. These patients were seen every 1-3 months. If the patients continued to be in a euthyroid state and to have negative TSAb and negative TBII at 1 year after ATD discontinuation, they were considered to be in remission (19). Of these 200 Graves' patients in group 1, 176 patients were in remission (group 1A) while the other 24 patients relapsed into hyperthyroidism (group 1B). No significant differences in the gender ratio, the ages at diagnosis, and the titers of TBII and TSAb before treatment were noted between groups 1 and 2 , or between groups $1 \mathrm{~A}$ and $1 \mathrm{~B}$. Significant differences in the durations of positive TBII, positive TSAb, and ATD treatment were noted between groups 1A and 1B. Early disappearances of TBII and TSAb predict the remission (22). We studied the frequencies of AA, AC,

Table 1 Clinical findings of the 252 Graves' patients.

\begin{tabular}{|c|c|c|c|c|c|c|c|}
\hline \multirow[b]{2}{*}{$\begin{array}{l}\text { Group } \\
\text { (number of cases) }\end{array}$} & \multirow[b]{2}{*}{ Women/men } & \multirow[b]{2}{*}{ Ages $^{a}$} & \multicolumn{2}{|c|}{ Before ATD treatment } & \multicolumn{3}{|c|}{ Durations (years) } \\
\hline & & & TBII (\%) & TSAb (\%) & + TBII & + TSAb & ATD treatment \\
\hline \multicolumn{8}{|l|}{ Group $1(200)^{b}$} \\
\hline Group 1A (176) ${ }^{\mathrm{C}}$ & $145 / 31$ & $38.5 \pm 16.5$ & $49.8 \pm 24.3$ & $592 \pm 196$ & $2.8 \pm 1.8$ & $3.0 \pm 1.8$ & $4.0 \pm 2.4$ \\
\hline Group 1B (24) & $19 / 5$ & $38.8 \pm 17.5$ & $50.1 \pm 21.5$ & $673 \pm 215$ & $5.3 \pm 2.4$ & $5.8 \pm 2.9$ & $6.9 \pm 2.9$ \\
\hline Group $2(52)^{\mathrm{e}}$ & $42 / 10$ & $38.0 \pm 19.5$ & $56.2 \pm 28.6$ & $779 \pm 395$ & \multicolumn{3}{|c|}{$\begin{array}{l}\text { Having positive TBII and/or TSAB } \\
\text { Taking ATD }\end{array}$} \\
\hline
\end{tabular}

Values are the means \pm s.D. ATD, antithyroid drugs; TBII, TSH-binding inhibitory immunoglobulin; TSAb, thyroid stimulating antibody. No significant differences in the ages at diagnosis and the titers of TBII and TSAb before treatment were noted between groups 1 and 2 , or between groups $1 \mathrm{~A}$ and $1 \mathrm{~B}$. Significant differences were noted between groups $1 \mathrm{~A}$ and 1B regarding the durations of positive TBII $(P=0.020)$, positive TSAb $(P=0.012)$, and ATD treatment $(P=0.018$; Student's $t$-test $)$.

agges: ages at diagnosis.

${ }^{\mathrm{b}}$ TBII and TSAb had disappeared. They discontinued ATD.

${ }^{\mathrm{c}}$ They continued to be in remission.

dThey relapsed into hyperthyroidism.

TBII and/or TSAb persisted. 
and $\mathrm{CC}$ genotypes and the $\mathrm{A}$ and $\mathrm{C}$ alleles of an $\mathrm{A} / \mathrm{C}$ polymorphism at position 8923 in PD-L1 gene.

The study plan was reviewed and approved by the institutional review committee. Written informed consent was obtained from both the Graves' patients and the control subjects.

\section{Genotyping}

DNA was extracted from peripheral blood using a DNA purification kit (Qiagen). The PD-L1 intron 4 position $8923 \mathrm{~A} / \mathrm{C}$ polymorphism was typed using the PCRrestriction fragment length polymorphism method (PCRRFLP). The appropriate segment of the PD-L1 gene was amplified using specific primers (5'-AATGGCTTGTTGTCCAGAGATG- $3^{\prime}$ and $5^{\prime}$-GTACCACATGGAGTGGCTGC-3') using premix Taq (Takara, Shiga, Japan). PCR was performed by initial denaturation for $10 \mathrm{~min}$ at $95^{\circ} \mathrm{C}$, annealing for $30 \mathrm{~s}$ at $60{ }^{\circ} \mathrm{C}$, extension for $3 \mathrm{~min}$ at $72^{\circ} \mathrm{C}$, denaturation for $30 \mathrm{~s}$ at $95{ }^{\circ} \mathrm{C}(37$ cycles), and a final extension for $10 \mathrm{~min}$ at $72^{\circ} \mathrm{C}$. The amplified products $(553$ bp) digested with restriction enzyme Ban II (Takara) and then analyzed on 3.0\% NuSiev GTG agarose (FMC BioProducts, Philadelphia, PA, USA) gels. The PCR fragments with a $\mathrm{C}$ allele at position 8923 were cut into three fragments $(97,130$, and $326 \mathrm{bp})$, whereas the fragments with $\mathrm{A}$ at the same position were cut into two fragments, namely they had the restriction site only at $97 \mathrm{bp}$ while also developing a $456 \mathrm{bp}$ band.

\section{Statistical analysis}

Statistical analyses were done using Fisher's exact test or Student's $t$-test. A value of $P<0.05$ was considered to be significantly different. Power and Hardy-Weinberg equilibrium calculations were performed using Excel (Microsoft Office Excel, 2003).

\section{Results}

Table 2 shows A/C SNP at position 8923 in the PD-L1 gene in the 327 Graves' patients and the 192 normal control subjects (controls). Significant differences in the A/C genotype frequencies were noted between Graves' patients and controls. The $\mathrm{A} / \mathrm{C}$ and $\mathrm{C} / \mathrm{C}$ genotype frequencies were higher in Graves' patients than in controls. The A/A genotype frequencies were lower in Graves' patients than in controls. The C-allele frequency in Graves' patients $(8.3 \%)$ was also higher than that in controls $(3.1 \%)$. Significant differences in the genotype frequencies $(P=0.0022)$ and the allele frequencies $(P=0.0009)$ were noted between Graves' patients and controls, producing an odds ratio $(\mathrm{OR})=2.79(95 \%$ confidence intervals $(\mathrm{CI})=1.47-5.28)$.

Table 3 shows genotype and allele frequencies of $\mathrm{A} / \mathrm{C}$ SNP PD-L1 at position 8923 in the 252 Graves' patients, who had been followed over 5-10 years. The A/C and C/C frequencies were 11.9 and $0.0 \%$ respectively in the 176 patients who continued to be in remission (group 1A), but the $\mathrm{A} / \mathrm{C}$ and $\mathrm{C} / \mathrm{C}$ genotype frequencies were 16.7 and $8.3 \%$ respectively in the other 24 patients who had relapsed into hyperthyroidism (group 1B). Significant differences in the genotype frequencies $(P=0.0102)$ were noted between the 176 (group 1A) and the other 24 (group 1B) patients. The C-allele frequency was $6.0 \%$ in the 176 (group 1A), but it was $16.7 \%$ in the other 24 (group 1B) patients. Significant differences in the allele frequencies $(P=0.0143)$ were noted between the 176 (group 1A) and the other 24 (group 1B) patients. Significant differences in the A- and C-allele frequencies were noted between groups $1 \mathrm{~A}$ and $1 \mathrm{~B}$, between groups 1 and 2 , and between groups $1 \mathrm{~A}$ and 2 . However, no significant differences in the $\mathrm{A}$ - and $\mathrm{C}$-allele frequencies were noted between groups $1 \mathrm{~B}$ and 2 .

\section{Discussion}

These data demonstrate the association of a PD-L1 gene polymorphism with GD. An A/C polymorphism at position 8923 in PD-L1 gene is associated with the GD development and also with a relapse of Graves' hyperthyroidism.

GD develops as a result of a complex interaction between genetic susceptibility genes and environmental factors $(23,24)$. A model analysis suggests that the GD

Table 2 Genotype and allele frequencies of A/C SNP PD-L1 gene at position 8923 in 327 Graves' patients (Graves') and 192 normal control subjects (controls).

\begin{tabular}{lcccc}
\hline & Graves' $\boldsymbol{n}(\%)$ & Controls $\boldsymbol{n}(\%)$ & $\boldsymbol{P}$ & OR \\
\hline Genotype & & & & \\
A/A & $277(84.7)$ & $181(94.3)$ & 0.0022 & \\
A/C & $46(14.1)$ & $10(5.2)$ & & \\
C/C & $4(1.2)$ & $1(0.5)$ & & \\
Allele & $600(91.7)$ & $372(96.9)$ & 0.0009 & 2.79 \\
A & $54(8.3)$ & $12(3.1)$ & & $1.47-5.28$ \\
C & & & & \\
\hline
\end{tabular}

PD-L1, programmed cell death-ligand 1; SNP, single nucleotide polymorphism; OR, odds ratio; $95 \% \mathrm{Cl}, 95 \%$ confidence intervals. Statistically significant differences were noted between Graves' patients and normal control subjects in the genotype frequencies $(P=0.0022)$ and allele frequencies $(P=0.0009)$. Statistical analyses were done using Fisher's exact test. 
Table 3 Genotype and allele frequencies of A/C SNP PD-L1 gene at position 8923 in the 252 Graves' patients.

\begin{tabular}{lccc}
\hline \multicolumn{4}{c}{ Group 1 (200) } \\
\cline { 2 - 3 } & $\begin{array}{c}\text { A. Remission } \\
(176) n(\%)\end{array}$ & $\begin{array}{c}\text { B. Relapsed } \\
(24) n(\%)\end{array}$ & $\begin{array}{c}\text { Group 2 (52) } \\
\boldsymbol{n}(\%)\end{array}$ \\
\hline Genotype & & & \\
A/A & $155(88.1)$ & $18(75.0)$ & $38(73.0)$ \\
A/C & $21(11.9)$ & $4(16.7)$ & $12(23.1)$ \\
C/C & $0(0.0)$ & $2(8.3)$ & $2(3.8)$ \\
Allele & $331(94.0)$ & $40(83.3)$ & $88(84.6)$ \\
A & $21(6.0)$ & $8(16.7)$ & $16(15.4)$ \\
C & &
\end{tabular}

PD-L1, programmed cell death-ligand 1; SNP, single nucleotide polymorphism; ATD, antithyroid drugs. Significant differences in A- and C-allele frequencies were noted between groups 1A and 1B $(P=0.0143)$, between groups 1 and $2(P=0.0187)$, and between groups $1 \mathrm{~A}$ and $2(P=0.0037$; Fisher's exact test). However, no significant differences in $\mathrm{A}$, the C-allele frequencies were observed between groups 1B and $2(P=0.8154$; Fisher's exact test).

patients have genetic susceptibility (25). The putative susceptibility genes for GD are immune-modifying genes (e.g., major histocompatibility complex $(\mathrm{MHC})(24,25)$, MHC class 1 chain-related gene A (MICA) (26), cytotoxic T-lymphocyte-associated antigen-4 (CTLA-4) (27), CD40 (28), and butyrophilin-like protein (BTNL2) that is likely due to a linkage disequilibrium with $\mathrm{MHC}$ class II (29)), thyroid-specific genes (e.g., TG (30) and TSH receptor (TSHR) (31)), cytokine-related genes (e.g., interleukin-1 receptor antagonist (IL-1RA) (32), IL-4 (33), and tumor necrosis factor- $\alpha$ (TNF- $\alpha$ ) (34)). A recent study has shown that small effects within a PD-1 gene may contribute to the GD development (17).

Programmed death-1 (PD-1; a CD28 homologue) and its ligands (PD-L1 and PD-L2; homologous to B7) constitute an inhibitory pathway of T-cell co-stimulation. PD-1/PD-L1 interactions play a critical role in the positive selection of thymocytes while also playing a role in shaping the T-cell repertoire (35). PD-L1 is expressed on activated T cells, B cells, monocytes, dendritic cells, and on non-hematopoietic cells (35-41). PD-1-PD-L1 interaction has been suggested to play a central role in the regulation of induction and progression of autoimmune diabetes in NOD mice (42). PD-1-/ - and PD-L1 - / - mice developed more severe EAE than wildtype and PD-L2 - / - mice (43). PD-1-PD-L1 interaction attenuates T-cell responses. A reduction of the PD-1/PDL1 function (or expression) augments the T-cell responses, and it may also induce autoimmune diseases.

PD-1 gene polymorphisms have been reported to be associated with SLE (9, 10), AS (15), MS (14), T1D (12), and GD (17). The genotype frequency of PD-L2 47103 $\mathrm{T} / \mathrm{T}$, in comparison with $47103 \mathrm{C} / \mathrm{C}$, has been reported to significantly increase in patients with SLE (16). A PD-L1 gene polymorphism has not been studied yet. This is the first report to demonstrate that a PD-L1 gene polymorphism is associated with autoimmune diseases. The C-allele frequency at position 8923 in the PD-L1 gene was higher in the GD patients than in the controls.
Graves' patients with a C allele at position 8923 in the PD-L1 gene had difficulty in achieving remission. An A/C polymorphism at position 8923 in the PD-L1 gene is associated with GD development and its remission.

This A/C polymorphism at position 8923 in the PD-L1 gene occurs in intron 4 . It does not affect an amino acid substitution. One possible explanation is that the polymorphism is near or within transcriptional factorbinding sites (12), and it may also modify the binding affinity of transcriptional factors. This may influence the PD-L1 gene expression. It is also possible that position 8923 A/C SNP may affect the PD-L1 function.

There are seven SNPs in the PD-L1 gene in the Japanese population. Six SNPs are in introns and one SNP is in $3^{\prime}$-UTR in the PD-L1 gene. The A/C polymorphism at position 8923 in the PD-L1 gene is associated with the GD development and its relapse. The other six SNPs will be analyzed.

Several GD-susceptibility genes contribute to the GD development with high ORs. For example, the development of GD could be due to the genetic effects of MHC such as DRB1*03 with OR values 2.3-3.4 (44). The genotype A5.1/A5.1 in MICA gene occurred more frequently in patients with GD than in the controls (OR 2.0) (45). The A49G and CT60 polymorphisms of CTLA-4 were significant in associations with GD (OR 1.49 and 1.45 respectively) (46). The CC+CT genotypes of the CD40-E1SNP were associated with the increased risk for GD (OR 1.9) (47). For TG gene, the three SNPs of the exons 10-12 in combination with the exon 33 SNP were strongly associated with GD with ORs 2.44-2.58 (30). In addition, the allele frequencies of $1031 \mathrm{C}$ and $-863 \mathrm{~A}$ of TNF- $\alpha$ gene in the GD patients with evident ophthalmopathy were significantly greater than those with no or mild ophthalmopathy (ORs 2.94 and 2.30 respectively) (34). Some genes may affect the GD development with low ORs (17). The rs2076530 SNP in BTLN2 gene and +2375 SNP in PD-1 gene were associated with the development of GD, but these genetic effects were small (ORs 1.32 and 1.14 respectively) $(17,29)$. Our PD-L1 gene polymorphism at 8923 contributes to the GD development with a high OR of 2.79 . It is still unclear whether this PD-L1 gene polymorphism strongly contributes to the GD development, because the number of patients and controls in our study was small and the allele frequency at position 8923 in the PD-L1 gene was minor. Occasionally, several factors have been shown to induce high ORs in similar studies with disease susceptibility genes. For example, studies with a small number of patients may generate high ORs. The OR of the development of GD with MHC gene is 2.3-3.4 in 135 GD patients (44), while that with MICA gene is 2.0 in 129 GD patients (45), that with CD40 gene is 1.9 in 301 GD patients (47), that with TG gene is 2.44-2.58 in 186 GD patients (30), and that with TNF- $\alpha$ gene is 2.94 in 173 GD patients (34). On the other hand, the OR of the development of GD with CTLA-4 gene is 1.49 
in 22038 GD patients (46), that with BTNL-2 gene is 1.32 in 1658 GD patients (29), and that with PD-1 gene is 1.14 in $4130 \mathrm{GD}$ patients (17). We performed the power calculations with the distribution of the PD-L1 gene polymorphism in the 327 GD patients and the 192 controls. The power was therefore $24 \%$ to detect an $\mathrm{OR}=1.5$ and $P=0.05$. Our PD-L1 gene polymorphism at 8923 contributes to the GD development with an OR of 2.79 . This OR of 2.79 seems to be high. The minor frequency of the $\mathrm{C}$ allele may generate this high OR. The C-allele frequency in the Graves' patients $(8.3 \%)$ was higher than that in the controls (3.1\%), the difference being $5.2 \%$. This could thus have produced the erroneously high OR of 2.79. There are some limitations in our study.

We describe that A/C SNP at 8923 might be one of the candidate gene polymorphisms for GD. Further studies will be required to determine a clear association of the PD-L1 gene polymorphism with the GD development in large numbers of patients, as well as patients with other different genetic backgrounds.

\section{Disclosure}

We have no conflict of interest that would prejudice its impartiality.

\section{References}

1 Heward J \& Gough SC. Genetic susceptibility to the development of autoimmune disease. Clinical Science 199793 479-491.

2 Brix TH, Kyvik KO, Christense K \& Hegedus L. Evidence for a major role of heredity in Graves' disease: a population-based study of two Danish twin cohorts. Journal of Clinical Endocrinology and Metabolism 200186 930-934.

3 Freeman GJ, Long AJ, Iwai Y, Bourque K, Chernova T, Nishimura H, Fitz LJ, Malenkovich N, Okazaki T, Byrne MC, Horton HF, Fouser L, Carter L, Ling V, Bowman MR, Carreno BM, Collins M, Wood CR \& Honjo T. Engagement of the PD-1 immunoinhibitory receptor by a novel B7 family member leads to negative regulation of lymphocyte activation. Journal of Experimental Medicine 2000192 1027-1034.

4 Salama AD, Chitnis T, Imitola J, Ansari MJ, Akiba H, Tushima F, Azuma M, Yagita H, Sayegh MH \& Khoury SJ. Critical role of the programmed death-1 (PD-1) pathway in regulation of experimental autoimmune encephalomyelitis. Journal of Experimental Medicine 2003198 71-78.

5 Najafian N \& Khoury SJ. T cell costimulatory pathways: blockade for autoimmunity. Expert Opinion on Biological Therapy 2003 3 227-236.

6 Latchman Y, Wood CR, Chernova T, Chaudhary D, Borde M, Chernova I, Iwai Y, Long AJ, Brown JA, Nunes R, Greenfield EA, Bourque K, Boussiotis VA, Carter LL, Carreno BM, Malenkovich N, Nishimura H, Okazaki T, Honjo T, Sharpe AH \& Freeman GJ. PD-L2 is a second ligand for PD-1 and inhibits T cell activation. Nature Immunology 20012 261-268.

7 Brown JA, Dorfman DM, Ma FR, Sullivan EL, Munoz O, Wood CR, Greenfield EA \& Freeman GJ. Blockade of programmed death-1 ligands on dendritic cells enhances T cell activation and cytokine production. Journal of Immunology 2003170 1257-1266.

8 Hatachi S, Iwai Y, Kawano S, Morinobu S, Kobayashi M, Koshiba M, Saura R, Kurosaka M, Honjo T \& Kumagai S. CD4+
PD-1 + T cells accumulate as unique anergic cells in rheumatoid arthritis synovial fluid. Journal of Rheumatology $2003 \mathbf{3 0}$ 1410-1419.

9 Prokunina L, Castillejo-Lopez C, Oberg F, Gunnarsson I, Berg L, Magnusson V, Brookes AJ, Tentler D, Kristjansdottir H, Grondal G, Bolstad AI, Svenungsson E, Lundberg I, Sturfelt G, Jonssen A, Truedsson L, Lima G, Alcocer-Varela J, Jonsson R, Gyllensten UB, Harley JB, Alarcon-Segovia D, Steinsson K \& AlarconRiquelme ME. A regulatory polymorphism in PDCD1 is associated with susceptibility to systemic lupus erythematosus in humans. Nature Genetics 200232 666-669.

10 Ferreiros-Vidal I, Gomez-Reino JJ, Barros F, Carracedo A, Carreira P, Gonzalez-Escribano F, Liz M, Martin J, Ordi J, Vicario JL \& Gonzalez A. Association of PDCD1 with susceptibility to systemic lupus erythematosus: evidence of population-specific effects. Arthritis and Rheumatism $2004502590-2597$.

11 Nielsen C, Hansen D, Husby S, Jacobsen BB \& Lillevang ST. Association of a putative regulatory polymorphism in the PD-1 gene with susceptibility to type 1 diabetes. Tissue Antigens 2003 62 492-497.

12 Ni R, Ihara K, Miyako K, Kuromaru R, Inuo M, Kohno H \& Hara T. PD-1 gene haplotype is associated with the development of type 1 diabetes mellitus in Japanese children. Human Genetics 2007121 223-232.

13 Prokunina L, Padyukov L, Bennet A, de Faire U, Wiman B, Prince J, Alfredsson L, Klareskog L \& Alarcon-Riquelme M. Association of the PD-1.3A allele of the PDCD1 gene in patients with rheumatoid arthritis negative for rheumatoid factor and the shared epitope. Arthritis and Rheumatism 200450 1770-1773.

14 Kroner A, Mehling M, Hemmer B, Rieckmann P, Toyka KV, Maurer M \& Wiendl H. A PD-1 polymorphism is associated with disease progression in multiple sclerosis. Annals of Neurology 2005 58 50-57.

15 Lee SH, Lee YA, Woo DH, Song R, Park EK, Ryu MH, Kim YH, Kim KS, Hong SJ, Yoo MC \& Yang HI. Association of the programmed cell death 1 (PDCD1) gene polymorphism with ankylosing spondylitis in the Korean population. Arthritis Research and Therapy 20068 R163.

16 Wang SC, Lin CH, Ou TT, Wu CC, Tsai WC, Hu CJ, Liu HW \& Yen JH. Ligands for programmed cell death 1 gene in patients with systemic lupus erythematosus. Journal of Rheumatology $2007 \mathbf{3 4}$ 721-725.

17 Newby PR, Roberts-Davies EL, Brand OJ, Heward JM, Franklyn JA, Gough SCL \& Simmonds MJ. Tag SNP screening of the PDCD1 gene for association with Graves' disease. Clinical Endocrinology 2007 67 125-128.

18 Takasu N, Kamijo K, Sato Y, Yoshimura H, Nagata A \& Ochi Y. Sensitive thyroid-stimulating antibody assay with high concentrations of polyethylene glycol for the diagnosis of Graves' disease. Clinical and Experimental Pharmacology and Physiology 200431 314-319.

19 Kinjo Y, Takasu N, Komiya I, Tomoyose T, Takara M, Kouki T, Shimajiri Y, Yabiku K \& Yoshimura H. Remission of Graves' hyperthyroidism and $\mathrm{A} / \mathrm{G}$ polymorphism at position 49 in exon 1 of cytotoxic T lymphocyte-associated molecule- 4 gene. Journal of Clinical Endocrinology and Metabolism $2002872593-2596$.

20 Takasu N, Oshiro C, Akamine H, Komiya I, Nagata A, Sato Y, Yoshimura H \& Ito K. Thyroid-stimulating antibody and TSHbinding inhibitor immunoglobulin in 277 Graves' patients and in 686 normal subjects. Journal of Endocrinological Investigation 1997 20 452-461.

21 Campbell G. Advances in statistical methodology for the evaluation of diagnostic and laboratory tests. Statistics in Medicine 199413 499-508.

22 Takasu N, Yamashiro K, Komiya I, Ochi Y, Sato Y \& Nagata A. Remission of Graves' hyperthyroidism predicted by smooth decreases of thyroid-stimulating antibody and thyrotropin-binding inhibitor immunoglobulin during antithyroid drug treatment. Thyroid $200010891-896$.

23 Heward J \& Gough SC. Genetic susceptibility to the development of autoimmune disease. Clinical Science 199793 479-491. 
24 Brix TH, Kyvik KO, Christensen K \& Hegedus L. Evidence for a major role of heredity in Graves' disease: a population-based study of two Danish twin cohorts. Journal of Clinical Endocrinology and Metabolism 200186 930-934.

25 Simmonds MJ \& Gough SC. Unravelling the genetic complexity of autoimmune thyroid disease: HLA, CTLA-4 and beyond. Clinical and Experimental Immunology 2004136 1-10.

26 Ota M, Katsuyama Y, Mizuki N, Ando H, Furihata K, Ono S, Pivetti-Pezzi P, Tabbara KF, Palimeris GD, Nikbin B, Davatchi F, Chams H, Geng Z, Bahram S \& Inoko H. Trinucleotide repeat polymorphism within exon 5 of the MICA gene (MHC class I chain-related gene A): allele frequency data in the nine population groups Japanese. Tissue Antigens 199749 448-454.

27 Kouki T, Sawai Y, Gardine CA, Fisfalen ME, Alegre ML \& DeGroot LJ. CTLA-4 gene polymorphism at position 49 in exon 1 reduces the inhibitory function of CTLA- 4 and contributes to the pathogenesis of Graves' disease. Journal of Immunology $2000 \mathbf{1 6 5}$ 6606-6611.

28 Tomer Y, Concepcion E \& Greenberg DA. A C/T single-nucleotide polymorphism in the region of the CD40 gene is associated with Graves' disease. Thyroid 200212 1129-1135.

29 Simmonds MJ, Heward JM, Barrett JC, Franklyn JA \& Gough SC. Association of the BTNL2 rs2076530 single nucleotide polymorphism with Graves' disease appears to be secondary to DRB1 exon 2 position beta74. Clinical Endocrinology $2006 \mathbf{6 5} 429-432$.

30 Ban Y, Greenberg DA, Concepcion E, Skrabanek L, Villanueva R \& Tomer Y. Amino acid substitutions in the thyroglobulin gene are associated with susceptibility to human and murine autoimmune thyroid disease. PNAS 2003100 15119-15124.

31 Bahn RS, Dutton CM, Heufelder AE \& Sarkar G. A genomic point mutation in the extracellular domain of the thyrotropin receptor in patients with Graves' ophthalmopathy. Journal of Clinical Endocrinology and Metabolism 199478 256-260.

32 Blakemore AI, Watson PF, Weetman AP \& Duff GW. Association of Graves' disease with an allele of the interleukin-1 receptor antagonist gene. Journal of Clinical Endocrinology and Metabolism $199580111-115$.

33 Hunt PJ, Marshall SE, Weetman AP, Bell JI, Wass JA \& Welsh KI. Cytokine gene polymorphisms in autoimmune thyroid disease. Journal of Clinical Endocrinology and Metabolism 2000 85 1984-1988.

34 Kamizono S, Hiromatsu Y, Seki N, Bednarczuk T, Matsumoto H, Kimura A \& Itoh K. A polymorphism of the $5^{\prime}$ flanking region of tumour necrosis factor alpha gene is associated with thyroidassociated ophthalmopathy in Japanese. Clinical Endocrinology 200052 759-764.

35 Keir ME, Latchman YE, Freeman GJ \& Sharpe AH. Programmed death-1 (PD-1): PD-ligand 1 interactions inhibit TCR-mediated positive selection of thymocytes. Journal of Immunology 2005175 $7372-7379$.

36 Keir ME, Liang SC, Guleria I, Latchman YE, Qipo A, Albacker LA, Koulmanda M, Freeman GJ, Sayegh MH \& Sharpe AH. Tissue expression of PD-L1 mediates peripheral T cell tolerance. Journal of Experimental Medicine 2006203 883-895.
37 Greenwald RJ, Freeman GJ \& Sharpe AH. The B7 family revisited. Annual Review of Immunology 200523 515-548.

38 Liang SC, Latchman YE, Buhlmann JE, Tomczak MF, Horwitz BH, Freeman GJ \& Sharpe AH. Regulation of PD-1, PD-L1, and PD-L2 expression during normal and autoimmune responses. European Journal of Immunology $2003332706-2716$.

39 Rodig N, Ryan T, Allen JA, Pang H, Grabie N, Chernova T, Greenfield EA, Liang SC, Sharpe AH, Lichtman AH \& Freeman GJ. Endothelial expression of PD-L1 and PD-L2 down-regulates CD8+ $\mathrm{T}$ cell activation and cytolysis. European Journal of Immunology 200333 3117-3126.

40 Ishida M, Iwai Y, Tanaka Y, Okazaki T, Freeman GJ, Minato N \& Honjo T. Differential expression of PD-L1 and PD-L2, ligands for an inhibitory receptor PD-1, in the cells of lymphohematopoietic tissues. Immunology Letters $20028457-62$.

41 Tseng SY, Otsuji M, Gorski K, Huang X, Slansky JE, Pai SI, Shalabi A, Shin T, Pardoll DM \& Tsuchiya H. B7-DC, a new dendritic cell molecule with potent costimulatory properties for $\mathrm{T}$ cells. Journal of Experimental Medicine 2001193 839-846.

42 Ansari MJ, Salama AD, Chitnis T, Smith RN, Yagita H, Akiba H, Yamazaki T, Azuma M, Iwai H, Khoury SJ, Auchincloss H Jr \& Sayegh MH. The programmed death-1 (PD-1) pathway regulates autoimmune diabetes in nonobese diabetic (NOD) mice. Journal of Experimental Medicine 2003198 63-69.

43 Carter LL, Leach MW, Azoitei ML, Cui J, Pelker JW, Jussif J, Benoit S, Ireland G, Luxenberg D, Askew GR, Milarski KL, Groves C, Brown T, Carito BA, Percival K, Carreno BM, Collins M \& Marusic S. PD-1/PD-L1, but not PD-1/PD-L2, interactions regulate the severity of experimental autoimmune encephalomyelitis. Journal of Neuroimmunology 2007182 124-134.

44 Hunt PJ, Marshall SE, Weetman AP, Bunce M, Bell JI, Wass JA \& Welsh KI. Histocompatibility leucocyte antigens and closely linked immunomodulatory genes in autoimmune thyroid disease. Clinical Endocrinology 200155 491-499.

45 Ide M, Dittmar M, Wurm M, Kanitz M \& Kahaly GJ. Polymorphisms of MICA microsatellites in thyroidal autoimmunity. Medizinische Klinik $2007 \mathbf{1 0 2} 11-15$.

46 Kavvoura FK, Akamizu T, Awata T, Ban Y, Chistiakov DA, Frydecka I, Ghaderi A, Gough SC, Hiromatsu Y, Ploski R, Wang PW, Ban Y, Bednarczuk T, Chistiakova EI, Chojm M, Heward JM, Hiratani H, Juo SH, Karabon L, Katayama S, Kurihara S, Liu RT, Miyake I, Omrani GH, Pawlak E, Taniyama M, Tozaki T \& Ioannidis JP. Cytotoxic T-lymphocyte associated antigen 4 gene polymorphisms and autoimmune thyroid disease: a meta-analysis. Journal of Clinical Endocrinology and Metabolism 200792 3162-3170.

47 Ban Y, Tozaki T, Taniyama M, Tomita M \& Ban Y. Association of a $\mathrm{C} / \mathrm{T}$ single-nucleotide polymorphism in the $5^{\prime}$ untranslated region of the CD40 gene with Graves' disease in Japanese. Thyroid 2006 $16443-446$.

Received 12 February 2008

Accepted 2 March 2008 